\title{
Assessment of American Mythic Paradigm in the Light of Liberty, Equality, Fraternity and Self- Knowledge: A Case of Le Roi Jones/Amiri Baraka, "Dutchman, 1964"
}

\author{
Jane Edward \\ Mkwawa University College of Education, Iringa, Tanzania
}

\begin{abstract}
The modern myth of black assimilation has been practiced by many African American in their work of art. Arthur Miller, Le Roi Jones/Amiri Baraka and Sam Shepard are some of famous authors in this doctrine. Each author in his time to a certain extent managed to explore the mythic context of America in addressing central issue which constrained blacks, such as adoption of norms and values in the middle of oppressing white society. Le Roi Jones in his play "Dutchman, 1964" addressed the key issues of race and racism as blacks strives to understand whites on the one hand and on the other hand demanding their identity to be acknowledged. This is a review paper which expounds this contradiction in America over centuries. It uses documentation as the main source of information. This paper narrates the Civil Rights movement which took place in 1960s, and it initiated the Act which made provision of fair voting to both races, use of public facilities, education and employment practices as well as abolition of segregation which was not practiced before. Le Roi Jones draws his tittle "Dutchman" from the myth of "The Flying Dutchman" a black captain who was doomed to perish due to the refusal of turning the ship to the opposite direction of the face of the storm and later he and the crew disappeared forever in the storm. The myth goes perpendicular with Clay, a black American young man who tries to seek identity by assimilating to white culture, Lula, a white prostitute who later stabs him to death. In this paper, which is largely based on textual analysis, we are going to discuss on the black Americans struggles towards building their identity, their success, limitation and knowledge, which is the fundamental entity towards any achievement in life, being positive or negative. We conclude that while demand for rights is imperative, it is equally important to keenly look at the extent to which the people who demand such rights conform to the rules and laws of the land.
\end{abstract}

Keywords: Assimilation, Civil rights, black Americans, race and racism, norms, values.

\section{INTRODUCTION}

America is a land of diverse traditions and custom due to its natural stance of having number of people with different origins, which is influenced by different opportunities available across the territory. Over the long time, approximately in the beginning of $17^{\text {th }}$ century, it has been a question as who belong/own America, who has right to live in, acquire education, employment and all right as per human being concerns. This question is far from getting clear answer perhaps it will never have one. This confrontation is highly problematic from the time in memory to the present. It is not seriously to all races as opposed to whites but it is even worse as far as blacks are concerned. Thus, the Civil Rights movement was engineered by blacks such as Malcom X, William Du Bois, Martin Luther King Jr. and many more iconic figures. The black revolution is much more than the rights of the Negroes; it forces all Americans to face the interrelated flaws....it exposes all evils which are deep rooted in the whole structure of our society, and suggests that, radical reconstruction of the society is the key issue to be faced... "We shall overcome"... (Luther, 1965). "...the problem of the twentieth century is the problem of the color line... I believe that all men, black, brown, and white, are brothers..." (Du Bois, 1903). These two quotations give us the light to what was the main subject in the Civil Right movement. Blacks were demanding to be acknowledged in the faces of whites. Pertaining to this trend, it leads to the authors such as Amiri Baraka to develop/airing out his views of the situation in the form of dramatic dialogue (play), so to say "Dutchman".

In the middle of chaos Amiri Baraka took an opportunity which in turn gives account to the growth of modern American Drama. In his Autobiography he said, I took into this theatre to show my community the need of them to perform the same journey and be aware of the hell they are living in, 
so that they could abandon it. Baraka defines the new revolutionary theatre, as a theatre that MUST EXPOSE! ....This theatre should teach blacks their mistakes, a way of understanding themselves in order to make appropriate corrections (Barrios, 1995). Baraka's knowledge of his community inspires younger generation to write, criticizing the spheres of race and racism in America.

Amiri Baraka/Le Roi Jones blended his knowledge of incidences using a lot of symbolism and imaginations. Norman(2013) emphasize that academicians at times tend to use terms without giving meaning to them, hence jeopardizing the value of the literatures, since only academician will benefit from it as they are capable to articulate the meaning of the articles and other works. In this view, we find it pertinent to provide meaning to some key concepts in this paper as they are expounded in "Dutchman". The title of the play, "Dutchman", is a symbol of the myth of "FlyingDutchman". A captain who was doomed to sail forever in the underground across the world because he refuse to turn his vessel in the opposite direction of the storm. In this incidence some people managed to come out of the vessel slowly, but many died including the captain. A black man Clay, stand for an ability to cope with environment as the "clay soil" is stiff. A soil that is used in making bricks which are hard to break. Lula's apple to Clay is another symbol which may stand for Adam and Eve incident in the Eden Garden, to mention some. Also Baraka uses violent language which is used by blacks to differentiate them from whites. This beautiful collection of literary devices and other techniques in presenting his knowledge (content), made Le Roi Jones a winner of Obie award in 1964 (the best OffBroadway exhilarating dramatization of racial violence) of his time.

\section{LITERATURE REVIEW}

In accentuating the issue of race and racism, many authors attempt to unfold their views differently from different angles and perspectives. Amiri Baraka being one of the author in the 1960s, there are others who expounded the same subject of black struggles to self-emancipation from time to time. Eugene O'Neill in his play The Hairy Ape (1920), attempted to present the struggles of blacks in their attempt of becoming (searching for their belongingness). He uses the powerful figure Yank, who became aware of his surrounding through confrontation with capitalist regime presented by Mildred, a white lady. The black man ended up in a broken, disappointed, crushed and denied right to selfexplanation/expression. This situation alarm to the world that, the visibility of blacks is far from being recognized by whites. To some extent up to Baraka's era, blacks belong where whites command them to be. Although recently, it seems the blacks have tried hard to come out of this exploitative system.Some prominent Gurus in management argue that if we analyses the struggle of African people, we notice that the so called white people fostered the development of the black people (Norman, 2015). Norman further indicates that development is a war, each mankind need to work hard in order to develop, hence backwardness noted in the African continent has no connection with the so called deprivation from the white rather it was part of stages to develop (Norman, 1998; 2013).

In the line of gurus, we notice that the struggles of self-emancipation is needed as a step towards complete freedom. On the other hand, in Emperor Jones, (1921), O'Neill created powerful, masculine and self-confident figure "Jones" who had self-confrontation between his real self and the postured self. He deceive natives of the small Island for magic power possession, that he can only be killed by silver bullet. Due to this he was crowned to be the "Emperor". The art resembles the war of Majimaji (water war) in Tanzania where the Nguni tribe were made to believe that after taking sprinkling water bullets from the white people particularly German's would turn into water (Gama, 1995). We further notice that beside this struggles, the small Island was his Jones' destiny, after he escaped from prison (America in 1920s). He was imprisoned for killing a white man. Jones managed to establish his own powerful identity but at the end he fails because the identity established has no stronger and clear roots. At some point, Jones forget his originality of being discriminated by whites and became racist. He calls Island natives by names as, “...fool woods, black trash...” At the end, he goes back to where he belongs, in the forest closer to nature, he wanted to escape. He was killed by the bullet which he neglected. The fear due to early deception became the weapon of his own destruction. He proved his weakness, Smithers said, “...he had losthimself... ”Both O'Neill's plays are thereby showing how blacks were eager to be acknowledged. They use whatever means to be cognized but at the end it turn out negative. Their move was never successful. However, it was a good attempt which laid foundation to other blacks to struggle for equality.

In a different angle, Edward Albee in his book The Zoo Story (1959), he tries to show the life of Americans in America. He recalled that, in America, people live like animals in the zoo, they are barred by complacency, self-interests and indifference to one another. "Zoo" symbolize America as it 
appears to majority. Animals in the zoo are barred by bars but Americans are separated one another by absence of real human relationships. There is no sense of kindness, care, support or affection to each other's. Alienation is the dormant atmosphere in America. Albee molded Jerry, as a person who suffers this alienation. He says, "I have been to the zoo "Jerry told Peter while sitting on the bench" (Peter did not respond to Jerry), I, said I have been to the zoo, MISTER, I HAVE BEEN TO THE ZOO! Peter, mh...huh... what? Iam sorry, were you talking to me?" Pg.21. Jerry tries as much as he can to talk to Peter, may be his stresses/feeling of alienation could come out through sharing ideas but Peter did not support the talk.In this sense, it seems that Peter was occupied by stresses as well. Basically, the situation in America is not human supportive, but rather a hell. The tragic death of Jerry through knife exhibit the effects of alienation which American community suffers. Furthermore Hussein (2007), said that; isolation, loneliness, and frustration is the major subject to modern American drama. It is the reality as we are the witness of the race and racism controversy which lead to the over selfishness to the whites. This creates the huge gap which results to emotional trauma to blacks.

However Demeter (2007), gave his commendation on the unrest situation in America which was the common atmosphere in $20^{\mathrm{h}}$ century. In this era, racial discrimination reaches its apex to the extent, killing of blacks was almost normal incidents to witness. He said, on Saturday July, 1964 violence erupted in Harlem in reaction to the shooting of 15 year old black teenager. This was not serious as the riots of 1935 and again 1943 which resulted as a massive killing of blacks. On the other hand, one of the controversial statement was given by Chris Sprowal, leader of the civil right organization CORE, during the parading of the Harlem in 1964, following the killing of teenage. The statement proclaimed that "it is time to let 'the man'... know that if he does something to us, we are going to do something back" (Apple 16). These incidents arouse the anxieties which come to propound the civil right movements.

\section{DiSCUSSION}

This play is centered on the train subway with a young black man (Clay) in his twenties and a white prostitute (Lula) in her thirties. The override theme in this play is the brutal sphere of racism, which is hidden in the face of whites (Lula). The play open when Clay is inside the train wearing suit with tie and bottom as whites does, as well as reading books. He saw a woman (Lula) standing on the platform eating an apple, Lula join Clay in the train offering apple to Clay, Clay seems to refuse the offer but slowly accepts it. Lula seduces Clay in every way possible until he was caught in the middle of Lula's mission. While sitting next to Clay, Lula accused him in a race based statements. Instead of Clay being insulted and reacting, he tolerates her trying to cope with the situation. "It sounds like something we can do..." (pg.22), Clay is accepting to join the party that Lula suggested which he doesn't know yet. Lula tells Clay "I bet you never once thought you were a black nigger." Furthermore, Lula insults him making reference on his friend she said "Is Warren Enrighta tall skinny black boy with a phony English accent?" Lula made a lot of unbearable insults which annoys Clay but he tolerated her, trying to understand her value basically whites values and assimilate into their morals. Lula plays a game of surface communication exchanging ritual and sexual intimacy which to some extent shocks Clay, example, Lula said, "... you tried to make it with your sister at the age of $10 \ldots$... (pg. 9). This familiarity brought Clay closer to the whites without knowing that he is preparing his own destruction. Lula at her lever of conquering Clay, she uses a guess technique in correlating all common black lifestyle in America as means of getting Clay closer (It was just her common sense) and not that she knew much of Clays private life.

Lula invites herself in the party she guess Clay was in his way to, emphasizing they will continue to share the apple even inside the party. Despite of all these insults, Clay accepts her company and Lula even made a worst insult by calling him "A black Baudelaire" "black nigger" strange as it may seem, she at the end told Clay that all insults was just a joke, Clay tolerate her tries to appreciate the humor (pg. 19).

As play continues, more people are boarding the train because seats were empty and Lula claim to know them all. Clay asks if she was an actress as she seem knowing a lot but she denies, claiming it is again a lie (pg. 27). Lula seem to be a bit complicated and unpredictable stubborn lady. Lula breaks into dancing showing interest to have belly dance with Clay,"...yes, come on Clay. Let's do the nasty. Rub bellies. Rub bellies...shake it, shake it..." (pg. 30, 31). Clay did not like her energy which results 
into fight "... slap her as hard as he can across the mouth... (pg.33). After having heard enough, Clay breaks into serious emotional tortured speech, expressing his powerful new desire of strong identity, opposing the sphere of racial maltreatment. The confrontation made Lula stabbing Clay to death. Lula orders passengers to throw Clays dead body out of the train and the journey continues. In the next subway, a young Blackman board the train "...he sits few seats back to Lula... she turns and give him a long slow look..." (pg.37, 38). Lula is creating atmosphere of treating him the same way she did to the late Clay.

Le Roi Jones is essentially expounding the sexual, race and racism together with classes/economic implications in the dichotomy of the wicked black-white relationship in America. Lula is a symbol of whites who manipulates blacks, believing whites are superior and important than blacks. This demonstrates the levels of freedom in America to be boundless to whites as opposed to suppressive life of blacks. Langston Hunge's, a black Civil Right author in his poem "I, Too Sing America, 1967" reflects the situation of blacks doomed to work in the whites household, he said... they send me to eat in the kitchen...( $3^{\text {rd }}$ and $16^{\text {th }}$ verses $)$, in this circumstance, blacks were not allowed to mix with whites, and they were regarded as invisible people. It was invisible race in the sense of knowledge as well as moral virtue. Clay has to tolerate the situation hoping it was going to bring him change, perhaps it was going to be his step towards identity recognition in the faces of brutal whites but it turns the opposite.

On the other hand, Clay found himself in the middle of confusion of traditions. He dress, speak and behave like whites while claiming his black identity to be acknowledged. This is what Du Bois called "the crisis of double consciousness in America; one ever feels his two ness- an American, a Negro...two souls, two thoughts, two un -reconciled striving, two warring ideals in one dark body..." What is this black identity then? Perhaps, there were no clear set of what are blacks cultural codes, thus, they are not ready to claim for the separate black identity. Clay appearance and education to some extent made Lula to cast him in a stereotype and Clay went angry as well as defensive. Clay plan of change through assimilation exhibit a worst outcome, he has to pay for the consequences of his act (accepting Lula's apple), in a horrific way, death.

However, his intention was good but he did the right thing at a wrong time. He could have waited a bit, assessing the sphere of white's consciousness and their perceptions on that particular time before revealing his mission. By the way, Clay is a human and he tried his level best in initiating the black revolution regardless his tragic death. The cyclic nature of the play "Dutchman", probably suggests failure of blacks in achieving their true freedom and identity. Which remain a question of all time, who is black and what is black identity? Who is the owner of America? Perhaps, America is a territory of everyone that is why, it is very hard to locate the exact answers to these questions. On the other hand, it is very hard for the ongoing confrontation (in America)in the name of race and racism to end completely until and unless everyone is aware of the fact that we are all human and we are created equal before the almighty God, as well as before the law, (Lincoln, 1863).

Probably, the second Blackman who board the train after Clay's death will be the victim of Lula's white society (phallic knife) as Clay. However, Amiri Baraka is telling us that, Lula was not the object of love to Clay but as an object of racism. Had Clay accepted all mistreatments of Lula, he could be safe. Once he opens up to his intension it was the worst mistake he ever did. Lula's apple to Clay is to some extent is same as Eve's apple to Adam in the Eden Garden (A Christian myth) Apple is taken as a fruit of seduction which lead to destruction. Clay's feeling, attribute is what condemn him at the end. However, Clay is a good initiator of the change, we have to believe that change cannot happen in a drastic manner, (Rome was not built in a single day) it need time, peculiar knowledge, commitment and cooperation. So to say, black Americans have to join their hands in achieving their intentions. It is written that a seed has to be sawn on the ground in order to grow and give out many fruits, NgugiWaThiong'o in his novel "The Grain of Wheat, 1967" It was Ngugi reaction on massive deaths of Kenyans who participated in the war of independence from the hands of English men in 1960s. In the bible is written that "...verily, verily, I say unto you except a corn of wheat fall unto a ground and die, it abides alone: but if it dies it brings forth much fruit..." (John 12: 24)We believe that, Clay's death is a seed that is sown unto the ground (his blood) and it is going to bring awareness on the importance of equality, fraternity, liberty and self-knowledge, both to the whites and blacks 


\section{CONCLUSION}

Amiri Baraka's "Dutchman" may be the successful play in social formation because it addresses the problem of race in America which had been the disappointing issue for the long time, approximately since $17^{\text {th }} \mathrm{C}$. Its violence nature exposes the realistic spheres which is not bad if we call it the modern American Myth. It reflects most of the chaotic situations that are happening in America. For example, the increase in number of gun attacks as reported by CNN in 2016 which makes the total of 136 incidents, in each incident approximately 4 to 6 people were killed including the shooters. In addition, the act of exposing the dominant evils of white dominance over blacks, using modern drama perspective, Amiri Baraka open doors to the young scholars to follow his doctrine. However, this problem has to be addressed continuously with hope of achieving freedom, equality, fraternity, liberty and self-knowledge in America, the land of diverse race and cultures. However, the mission can delay but some day it is going to be attained. Success comes through hardworking towards determination as well as hope being the foremost thing to adhere. We appeal to the people of the world and in particular those who consider victims of the racism to differentiate between evils done by the same race and the actions of governments to combat such actions. As Norman (2013) puts it, most of the complaints of the people towards the governments which relate to racism need careful scrutiny as at times they are mere fallacies which are driven by the evils done by the complaints. It worthy to ensure conformity to rules and laws of the land while the demand for rights is advocated.

\section{REFERENCES}

[1] Albee, E. (1959).The Zoo Story. New York: Samuel French.

[2] Apple, R W.(1964). "Violence Flares Again in Harlem" New York Times $20^{\text {th }}$ July, 1964.

[3] Barrios, O.(1995). "Amiri Baraka: The Ritual of the History and the Self in The Slave" Universidad de Salamanca.

[4] Baraka, A. (1996). Othello Jr. Funk Lore. Los Angeles: Littoral. Pp. 88-92

[5] Demeter, J. (2007). "This is a Theatre of Assault": Amiri Baraka's Dutchman and Civil Rights Othello. The University of Akron, Vol.., 2007.

[6] Du Bois, W. (1903). The Soul of Black Folk. Chicago: A.C Mc Clurg and Co.

[7] Holy Bible. (1965). King James Version. John 12:24. Hendrickson.

[8] Hunges L. (1967). "I, Too Sing America” Boston: Harvard Berkley.

[9] Hussein, W. "The Zoo Story”. University of Basrah. Journal of the college of Arts; No. 43, 2007.

[10] Jones, Le Roi. (1964).Dutchman: The Cherry Lane Theatre, New York: William Morrow and Co.

[11] Lincoln, A. “Abraham Lincoln Speech”. Gettysburg Address, 1863.

[12] King, M.L (1965). "I have a Dream" New York.

[13] Norman, A.S.K. (2013). Conflict management among the pastoralist and farmers: A case of HAI District in Tanzania. International SAMANM Journal of Business and Social Sciences Vol. 1(2), pp.40-50.

[14] Norman, A.S.K (2015). African development bailout: Some strategies for development.

[15] Dar es Salaam: Tanzania Research Education and Environment care Association.

[16] Norman, A.S. (1998). The role of training in improving African continent. Ruhr University.

[17] Norman, PAWATS (2003). Globalization in the third world: Challenges and realities. Lefkosia.

[18] O’Neill, E. (1920). The Hairy Ape. Indo American Cooperative. New York. 1920

[19] O’Neill, E. (1920). The Emperor Jones. Provincetown Theatre. New York. 1920

[20] Prasanna, S. (2015). "Racial Violence of Marginalized in Amiri Baraka's Dutchman" Online International Interdisciplinary Research Journal; Vol. 5.

[21] WaThiong'o, N. A (1967). Grain of Wheat: Heinemann, Leeds University, 1967.

[22] Willingham J.(2016). “A Visual Guide: Mass Shooting in America” CNN, 2016. 